\title{
Nursing strategies for pressure injury prevention in surgical patients
}

\author{
Estratégias de enfermagem para prevenção de lesão por pressão \\ em pacientes cirúrgicos
}

\section{Estrategias de enfermería para la prevención de lesiones por presión en pacientes quirúrgicos}

\begin{abstract}
Sandra Marina Gonçalves Bezerra ${ }^{1, *}$, Jessyca Fernanda Pereira Brito ${ }^{1}$, Jefferson Abraão Caetano Lira ${ }^{1}$, Nanielle Silva Barbosa ${ }^{1}$, Kauan Gustavo de Carvalho' , Luana Silva de Sousa ${ }^{1}$
\end{abstract}

ORCID IDS

Bezerra SMG (D) https://orcid.org/0000-0003-3890-5887

Brito JFP (D) https://orcid.org/0000-0003-1438-4650

Lira JAC (iD https://orcid.org/0000-0002-7582-4157

Barbosa NS (D) https://orcid.org/0000-0001-5758-2011

Carvalho KG (iD https://orcid.org/0000-0002-9940-1837

Sousa LS (D) https://orcid.org/0000-0002-2415-8334

\section{HOW TO CITE}

Bezerra SMG; Brito JFP; Lira JAC; Barbosa NS; Carvalho KG; Sousa LS. Nursing strategies for pressure injury prevention in surgical patients ESTIMA, Braz. J. Enterostomal Ther., 18: e1020, 2020. https://doi. org/10.30886/estima.v18.793_IN

\begin{abstract}
Objective: To identify in the literature the strategies used by nursing teams to prevent pressure injury in surgical patients. Methods: Integrative review, using the PICo strategy, with the guiding question: "What are the strategies used by the nursing team to prevent pressure injury in surgical patients?" The searches were performed in the Web of Science, MEDLINE via PubMed, CINAHL, Cochrane, Scopus and LILACS bibliographic index via VHL, from where 12 studies were analyzed. Results: Brazil stood out with four publications and cohort studies, with level of evidence IV, prevailed in six articles. Technological interventions for the prevention of Pressure Injury in the operating room were pressure distribution mattresses, a device to reduce pressure on the calcaneus, specific validated instruments for the classification of the risk of Pressure Injury in surgical patients, in addition to support surfaces containing polymer viscoelastic and other tools to relieve pressure from weight and medical devices. Regarding educational interventions, protocols, training and realistic simulation stood out. Conclusion: It was observed that these strategies reduced the incidence of pressure injury, in addition to reducing costs and ensuring patient satisfaction.
\end{abstract}

DESCRIPTORS: Perioperative period. Intraoperative period. Pressure ulcer. Patient positioning. Nursing. Enterostomal therapy.

\begin{abstract}
RESUMO
Objetivo: Identificar na literatura as estratégias utilizadas por equipes de enfermagem para prevenção de lesão por pressão em pacientes cirúrgicos. Métodos: Revisão integrativa, utilizando a estratégia PICo, tendo como questão norteadora: "quais as estratégias utilizadas pela equipe de enfermagem para prevenção de lesão por pressão em pacientes cirúrgicos?" As buscas foram realizadas nas bases de dados Web of Science, MEDLINE via PubMed, CINAHL, Cochrane, Scopus e no índice bibliográfico LILACS via BVS, sendo analisados 12 estudos. Resultados: O Brasil se destacou com quatro publicações e os estudos de coorte, com nível de evidência IV, prevaleceram em seis artigos. As intervenções tecnológicas para prevenção de lesão por pressão no centro cirúrgico foram colchões para distribuição de pressão, dispositivo para redução de pressão no calcâneo, instrumentos validados específicos para a classificação do risco de lesão por pressão em pacientes cirúrgicos, além de superfícies de apoio contendo polímero viscoelástico e outros utensílios para alívio da pressão decorrente do peso e de dispositivos médicos. Com relação às intervenções educativas, destacaram-se os protocolos, os treinamentos e a simulação realística. Conclusão: Observou-se que essas estratégias reduziram a incidência de lesão por pressão, além de diminuírem os custos e garantirem a satisfação dos pacientes.
\end{abstract}

DESCRITORES: Período perioperatório. Período intraoperatório. Lesão por pressão. Posicionamento do paciente. Enfermagem. Estomaterapia.

1. Universidade Estadual do Piauí - Teresina (PI), Brazil.

*Correspondece author: sandramarina20@hotmail.com

Received: Aug. 13, 2019 | Accepted: Mar. 31, 2020 


\section{RESUMEN}

Objetivo: identificar en la literatura las estrategias utilizadas por el equipo de enfermería para prevenir lesiones por presión en pacientes quirúrgicos. Métodos: Revisión integral, utilizando el acrónimo PICo, con la pregunta guía: “¿Cuáles son las estrategias utilizadas por el equipo de enfermería para prevenir lesiones por presión en pacientes quirúrgicos?" Las búsquedas se realizaron en la Web of Science, MEDLINE vía PubMed, CINAHL, Cochrane, Scopus y LILACS vía BVS, siendo 12 estudios analizados. Resultados: Brasil se destacó con cuatro publicaciones y estudios de cohortes, con nivel de evidencia IV, prevaleció en seis artículos. Intervenciones tecnológicas para la prevención de lesiones por presión en la sala de operaciones fueron colchones de distribución de presión, un dispositivo para reducir la presión sobre el calcáneo, instrumentos específicos validados para la clasificación del riesgo de lesión por presión en pacientes quirúrgicos, además de superficies de soporte que contienen polímeros de herramientas viscoelásticas y otras para aliviar la presión del peso y los dispositivos médicos. En cuanto a las intervenciones educativas, se destacaron los protocolos, la capacitación y la simulación realista. Conclusión: se observó que estas estrategias redujeron la incidencia de lesiones por presión, además de reducir los costos y garantizar la satisfacción del paciente.

DESCRIPTORES: Periodo perioperatorio. Periodo intraoperatorio. Úlcera por presión. Posicionamiento del paciente. Enfermería. Estomaterapia.

\section{INTRODUCTION}

A pressure injury (PI), characterized as a damage located in the skin and/or in underlying soft tissues, generally on a bone prominence or related to the use of medical devices or other artifacts, affects the surgical patient due to prolonged immobility or intense pressure during surgical procedures, because the effect of anesthesia blocks sensitivity to pain and excessive pressure. In this sense, pressures greater than $32 \mathrm{mmHg}$ result in an occlusion of the blood flow, providing tissue ischemia and, consequently, $\mathrm{PI}^{1,2}$.

A surgical patient is someone who underwent manual or instrumental surgical intervention in order to diagnose or treat diseases. The surgical process is divided into three phases: preoperative, intraoperative and postoperative. Safe surgery is an important strategy to reduce the possibility of harm to the patient, and the prevention of skin lesions in surgical patients is one of the essential nursing care ${ }^{3,4}$.

The transfer to the operating room, postanesthesia recovery room and clinic of origin increases friction and/or shear and, consequently, generates risks for the emergence of PI. Thus, effective strategies used by the nursing team, such as health education, change of decubitus, use of devices and equipment to relieve pressure, are essential to maintain patient safety in the operating room and prevent $\mathrm{PI}$, in addition to ensuring the quality of care provided ${ }^{5}$.

A study conducted in Minas Gerais, in 2018, found that the half-yearly cost of PI treatment per hospitalized patient was $R \$ 1,886.00$, and the total cost was $R \$ 113,186.00^{6}$. In this sense, it should be noted that strategies for prevention of PI, despite having considerable expense, have a better cost benefit, since they provide a reduction in hospitalization, improved quality of life and indicators of prevalence and incidence of PI.

The incidence of PI in the surgical center varies from 7.0 to $17.6 \%$, which prolongs the length of hospitalization, generates an increase in hospital costs, as well as risk of infection and other consequences for patients, professionals and the institution. Pressure injury is the second most common legal claim in cases of death by negligence, with 17,000 lawsuits per year, as it is $100 \%$ avoidable, highlighting the importance of preventive strategies, since they would impact on a considered economy, whose resources could be used for other purposes, such as improving the quality of $\mathrm{care}^{7,8}$.

Pressure injuries cause emotional and physical suffering, as well as severe pain, delayed recovery and hospital discharge, which predisposes the patient to other complications and even death. In this perspective, it competes to the nurse, in the management of the assistance, the planning of effective strategies for the adequate positioning of the patient and the use of the equipment and surgical devices, besides the mobilization of the nursing team for the prevention of $\mathrm{PI}^{9}$.

This study aims to identify in the literature the strategies used by the nursing team to prevent pressure lesions in surgical patients.

\section{METHODS}

It is an integrative review of the literature developed in six stages, following the theoretical reference of Whittemore and $\mathrm{Knafl}^{10}: 1$ ) selection of the guiding 
question; 2) sampling or search in the literature; 3) selection of the researches that composed the sample; 4) extraction of data from the included studies; 5) evaluation and interpretation of the results; and 6) presentation of the review or synthesis of the knowledge produced.

The guiding question was elaborated from the acronym $\mathrm{PICo}^{11}$, where $\mathrm{P}=$ population: "surgical patient",
$\mathrm{I}=$ interest "strategies for prevention of pressure injury" and Co = context: "nursing care". Thus, the following research question was elaborated: "what are the strategies used by the nursing team to prevent pressure injuries in surgical patients?"

Articles from primary studies indexed in databases, published in English, Portuguese and Spanish, related

Table 1. Controlled, uncontrolled descriptors and search expressions used for article retrieval. Teresina (PI), Brazil, 2020.

\begin{tabular}{|c|c|c|}
\hline \multicolumn{3}{|r|}{ MeSH andCINAHL } \\
\hline \multirow{2}{*}{$\mathrm{P}$} & $C D$ & Perioperative period, Perioperative care, Intraoperative period \\
\hline & UCD & Perioperative period, Periods, perioperative, Perioperative care, Intraoperative period \\
\hline \multirow{2}{*}{ I } & $C D$ & Pressure ulcer, Patient positioning \\
\hline & UCD & Pressure ulcer, Pressure ulcers, Decubitus ulcer, Decubitus ulcers, Patient positioning \\
\hline \multirow{2}{*}{ Co } & $C D$ & Nursing care, Nursing \\
\hline & UCD & Nursing care, Nursing, Nursings \\
\hline \multirow{5}{*}{ 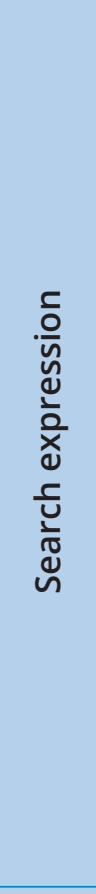 } & $\begin{array}{l}\text { MEDLINE } \\
\text { via } \\
\text { Pubmed }\end{array}$ & 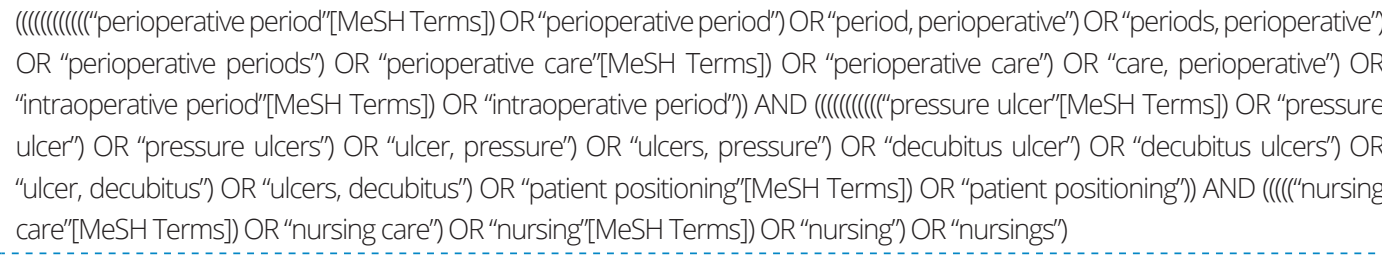 \\
\hline & $\begin{array}{l}\text { Web of } \\
\text { Science }\end{array}$ & $\begin{array}{l}(\mathrm{TS}=(\text { "perioperative period") OR TS=("perioperative periods") OR TS=("perioperative care") OR TS=("intraoperative } \\
\text { period")) AND (TS=("pressure ulcer") OR TS=("pressure ulcers") OR TS=("decubitus ulcer") OR TS=("decubitus } \\
\text { ulcers") OR TS=("patient positioning")) AND (TS=("nursing care") OR TS=(nursing) OR TS=(nursings)) }\end{array}$ \\
\hline & CINAHL & $\begin{array}{l}\text { ("perioperative period" OR (MH "Intraoperative Period") OR "perioperative periods" OR (MH "Perioperative Care") } \\
\text { OR "perioperative care" OR (MH "Perioperative Care (lowa NIC)")) AND ((MH "Pressure Ulcer") OR "pressure ulcer' } \\
\text { OR "pressure ulcers" OR "decubitus ulcer" OR (MH "Patient Positioning") OR "patient positioning") AND ((MH } \\
\text { "Nursing Care") OR "nursing care" OR "nursing" OR "nursings") }\end{array}$ \\
\hline & Cochrane & $\begin{array}{l}\text { (("perioperative period") OR ("perioperative periods") OR ("perioperative care") OR ("intraoperative period")) AND } \\
\text { (("pressure ulcer") OR ("pressure ulcers") OR ("decubitus ulcer") OR ("decubitus ulcers") OR ("patient positioning")) } \\
\text { AND (("nursing care") OR (nursing) OR (nursings)) }\end{array}$ \\
\hline & Scopus & $\begin{array}{l}\text { ((TITLE-ABS-KEY ("perioperative period") OR TITLE-ABS-KEY ("perioperative periods") OR TITLE-ABS-KEY ("perioperative } \\
\text { care") OR TITLE-ABS-KEY ("intraoperative period"))) AND ((TITLE-ABS-KEY ("pressure ulcer") OR TITLE-ABS-KEY } \\
\text { ("pressure ulcers") OR TITLE-ABS-KEY ("decubitus ulcer") OR TITLE-ABS-KEY ("decubitus ulcers") OR TITLE-ABS-KEY } \\
\text { ("patient positioning"))) AND ((TITLE-ABS-KEY("nursing care")OR TITLE-ABS-KEY(nursing) OR TITLE-ABS-KEY (nursings)), }\end{array}$ \\
\hline \multicolumn{3}{|r|}{ DeCS } \\
\hline \multirow{3}{*}{$\mathbf{P}$} & $C D$ & Período Perioperatório, Assistência Perioperatória, Período Intraoperatório \\
\hline & UCD & Período Perioperatório, Assistência Perioperatória, Cuidados Perioperatórios, Período Intraoperatório \\
\hline & $C D$ & Lesão por Pressão, Posicionamento do Paciente \\
\hline I & UCD & $\begin{array}{l}\text { Lesão por Pressão, Úlcera de Decúbito, Úlcera de Pressão, Úlcera por Pressão, Úlceras por Pressão, } \\
\text { Posicionamento do Paciente }\end{array}$ \\
\hline \multirow{2}{*}{ Co } & CD & Cuidados de Enfermagem, Enfermagem \\
\hline & UCD & Cuidados de Enfermagem, Assistência de Enfermagem, Enfermagem \\
\hline 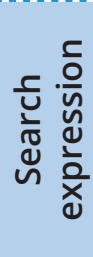 & $\begin{array}{l}\text { LILACS via } \\
\quad \text { BVS }\end{array}$ & 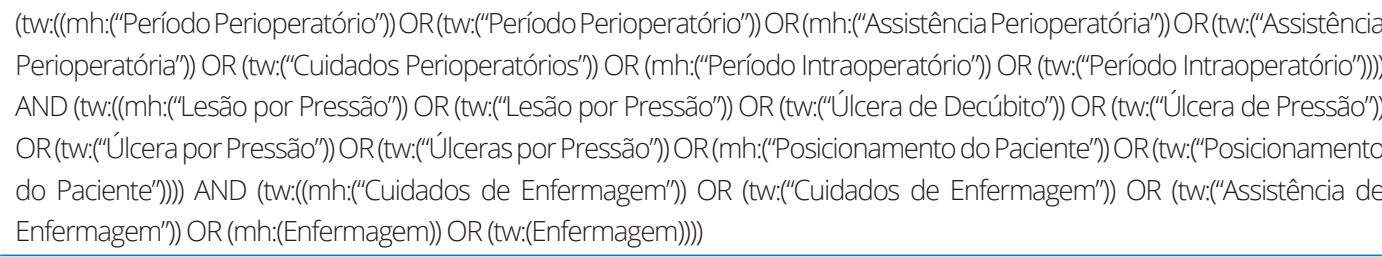 \\
\hline
\end{tabular}

CD (controlled descriptor); UCD (uncontrolled descriptor). 
to the subject of research and without temporal cutoff were listed as inclusion criteria. Notes, monographs, dissertations and theses were excluded.

The bibliographic survey was performed in January 2020 in the electronic databases Web of Science, Medical Literature Analysis and Retrieval System Online (MEDLINE via PubMed), Cumulative Index to Nursing and Allied Health Literature (CINAHLEbsco), Cochrane, Scopus and LILACS (Literatura Latino-Americana em Ciências da Saúde via BVS).

The controlled and uncontrolled descriptors were selected through consultation with the terms of Medical Subject Headings (MeSH), Health Sciences Descriptors (DeCS) and CINAHL Information Systems List of Headings. The search expressions were elaborated using the Boolean operators "OR" and "AND". Different search strategies were chosen, due to the peculiarities of the bases and the index. The syntax of searches is described in Table 1. The search expressions were developed using the Boolean operators "OR" and "AND”. Different search strategies were chosen due to particularities of the bases and the index. The search syntax is described in Table 1.
The access to the productions took place through the Portal of Periodics of the Coordenação de Aperfeiçoamento de Pessoal de Nivel Superior (CAPES). In order to minimize probable errors or biases in the assessment of studies, the selection was developed by two reviewers, independently, in two stages. In the first stage, the title and abstract were read, and in the second stage, the full text was read. In cases where disagreements occurred, there was discussion between the two evaluators to reach a consensus.

The search resulted in 288 productions. It should be noted that duplicate articles in more than one database or index were counted only once, with 33 being removed due to duplication. Thus, in the first stage, 255 articles were selected for the title and abstract reading. After the application of inclusion and exclusion criteria, 240 articles were discarded ( 15 were literature reviews, 183 were not related to the theme, 27 were notes and 15 were monographs, dissertations or theses). In the second stage, 15 articles were eligible for full text reading, with three productions being excluded as they did not address the research topic, with 12 articles remaining,

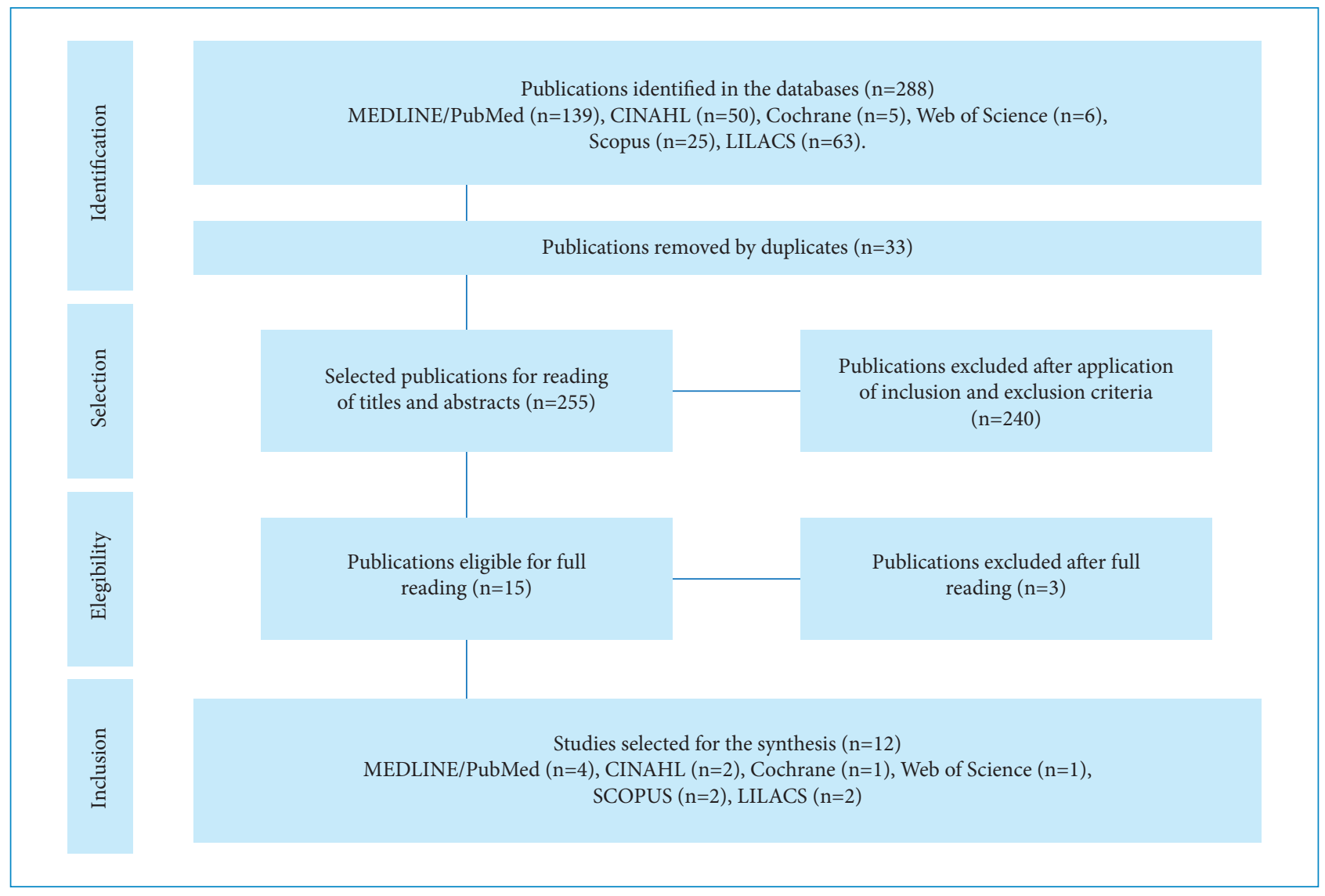

Figure 1. Flowchart of identification, selection, eligibility and inclusion of articles. Teresina (PI), Brazil, 2020. 
which composed the sample and were analyzed. Figure 1 describes the flow chart of the selected articles.

Data were extracted using a form containing information on article identification, country and year of publication, type of study, sample, intervention, main results and level of evidence from the studies. For this analysis, the evidence was classified according to the model proposed by Melnyk and Fineout-Overholt ${ }^{12}$ : level I - evidence from systematic review or meta-analysis of all relevant randomized controlled trials or from clinical guidelines based on systematic reviews of randomized controlled trials; level II - evidence derived from at least one well-designed randomized controlled trial; level III - evidence derived from well-designed clinical trials without randomization; level IV - evidence from well-designed cohort and case-control studies; level V - evidence from systematic review of descriptive and qualitative studies; level VI - evidence from a single descriptive or qualitative study; and level VII - from authorities' opinion and/or expert committee reports.

\section{RESULTS}

The synthesis of the findings was organized in Table 2 and the critical analysis made it possible to organize the results by semantic similarity, which allowed the construction of two categories: technological and educational interventions.

As for the country of publication, Brazil stood out with four productions. Regarding the type of study, six articles are cohort studies, with level of evidence IV. The main intervention was the protocols for PI prevention, with three publications. Moreover, it was identified that the interventions were effective in reducing the incidence of PI in surgical patients in all selected studies.

\section{DISCUSSION}

\section{Technological interventions}

Interventions applied in the prevention of PI are directly related to pressure relief during and after the patient's stay on the standard operating table mattress. This requires the implementation of preventive measures in the perioperative phases, i.e. pre-, intraand postoperative ${ }^{24}$.

In this context, scales to assess the risk of skin lesions in the operating room should be applied. It is worth noting that the Braden scale does not specifically assess risk factors in surgical patients, such as the duration of surgery, since one hour of surgery is capable of increasing by $1.07 \%$ the risk for developing $\mathrm{PI}^{17,25}$.

Specific intraoperative scales that evaluate the risk of lesions resulting from surgical positioning allow a more effective recognition of risk factors and contribute to the elaboration of an individualized care plan, which guarantees quality and safe perioperative care. Hence, the Munro scale was created as the first specific scale for identifying the risk of developing PI in surgical patients, and it has three sections: preoperative (mobility and body mass index), intraoperative (score of the American Society of Anesthesiologists, ASA, and body temperature) and postoperative (length of surgery and blood loss), where the risk level is scored for each phase, obtaining a cumulative score at the end ${ }^{26}$.

Another tool identified was the Scott Triggers' risk classification, which evaluates the patient's age, albumin or BMI levels, the rates recommended by ASA and the estimated duration of surgery, recommended by the United States Perioperative Nurses Association. In Brazil, the risk assessment scale for the development of surgical positioning injuries (ELPO) was developed and validated, and its score ranges from 7 to 35 points, where higher the score, higher the risk to develop lesions ${ }^{17,20}$.

The ELPO has seven items: type of surgical position, time of surgery, type of anesthesia, support surface, position of the limbs, comorbidities and patient's age. As it is a valid and reliable instrument to evaluate the risk of developing lesions due to surgical positioning, the application of ELPO can help the nurse's decision making, ensuring improved nursing care, patient safety and reduction of $\mathrm{PIs}^{1}$.

For interventions to be successful, effective devices are needed to prevent this type of injury. Thus, specialized support surfaces and structures, such as coatings, upholstery and integrated systems for weight redistribution, can be used in order to control pressure, shear and tissue friction, maintaining the microclimate and other therapeutic functions ${ }^{27}$.

The Clinitron Rite Hite bed was a postoperative strategy where the patient rests on a fluidized silicon 
Table 2. Synthesis of included productions addressing identification, year, country, type of study, sample, level of evidence, intervention and main results. Teresina (PI), Brazil, 2020.

\begin{tabular}{|c|c|c|c|c|}
\hline Article & $\begin{array}{l}\text { Year } \\
\text { and } \\
\text { country }\end{array}$ & $\begin{array}{l}\text { Type of study, sample and level } \\
\text { of evidence }\end{array}$ & Intervention & Main results \\
\hline $\mathrm{A} 1^{13}$ & $\begin{array}{l}2011 \\
\text { USA }\end{array}$ & $\begin{array}{l}\text { Cohort study; } 25 \text { patients } \\
\text { undergoing heart surgery; level IV }\end{array}$ & Clinitron Rite Hite bed & $\begin{array}{l}\text { It reduced the number of patients } \\
\text { who developed PI. There was no } \\
\text { progress in the stage of previously } \\
\text { developed injuries. }\end{array}$ \\
\hline $\mathrm{A} 2^{14}$ & $\begin{array}{l}1998, \\
\text { UK }\end{array}$ & $\begin{array}{l}\text { Controlled randomized clinical trial; } \\
246 \text { surgical patients from vascular } \\
\text { and gynecological clinic; level II }\end{array}$ & Dry viscoelastic polymer mattress & $\begin{array}{l}\text { It reduced the pressure on bone } \\
\text { prominences and, consequently, } \\
\text { the appearance of injuries. }\end{array}$ \\
\hline$A 3^{15}$ & $\begin{array}{l}\text { 2001, } \\
\text { USA }\end{array}$ & $\begin{array}{l}\text { Randomized controlled trial; } \\
324 \text { patients submitted to major } \\
\text { surgeries; level II }\end{array}$ & Therapy with heated blankets & $\begin{array}{l}\text { Reduced PI development rates, } \\
\text { promoting adequate blood } \\
\text { circulation and tissue oxygenation. }\end{array}$ \\
\hline $\mathrm{A} 4^{16}$ & $\begin{array}{l}2017 \\
\text { USA }\end{array}$ & $\begin{array}{l}\text { Cohort study; } 183 \text { patients } \\
\text { submitted to tracheostomy; level IV }\end{array}$ & $\begin{array}{l}\text { Care protocol for prevention of PI } \\
\text { in tracheostomy }\end{array}$ & $\begin{array}{l}\text { Reduced the incidence of PIs } \\
\text { caused by the tracheostomy tube. }\end{array}$ \\
\hline$A 5^{17}$ & $\begin{array}{l}\text { 2019, } \\
\text { Brazil }\end{array}$ & $\begin{array}{l}\text { Cohort study; } 278 \text { patients } \\
\text { submitted to elective surgical } \\
\text { interventions; level IV }\end{array}$ & $\begin{array}{c}\text { Risk assessment scale for the } \\
\text { development of surgical positioning } \\
\text { injuries (ELPO) }\end{array}$ & $\begin{array}{l}\text { Identified risk factors for the } \\
\text { development of injuries resulting } \\
\text { from surgical positioning. }\end{array}$ \\
\hline$A 6^{18}$ & $\begin{array}{l}2012 \\
\text { USA }\end{array}$ & $\begin{array}{l}\text { Cohort study; } 424 \text { employees of } \\
\text { two surgical centers; level IV }\end{array}$ & $\begin{array}{l}\text { Pressure injuries prevention } \\
\text { protocol }\end{array}$ & $\begin{array}{l}\text { Reduced the number of PIs by } \\
\text { of protocol and educational } \\
\text { interventions. }\end{array}$ \\
\hline$A 7^{19}$ & $\begin{array}{l}\text { 2017, } \\
\text { India }\end{array}$ & $\begin{array}{c}\text { Randomized controlled trial; } 40 \\
\text { employees of an operating room; } \\
\text { level II }\end{array}$ & Educational intervention & $\begin{array}{l}\text { Reduced risk factors for PI } \\
\text { development. }\end{array}$ \\
\hline
\end{tabular}

\begin{tabular}{|c|c|c|c|c|}
\hline $\mathrm{A} 8^{20}$ & $\begin{array}{l}\text { 2019, } \\
\text { USA }\end{array}$ & $\begin{array}{c}\text { Cohort study; } 100 \text { patients in an } \\
\text { operating room; level IV }\end{array}$ & $\begin{array}{l}\text { Low-profile alternating pressure } \\
\text { overlay }\end{array}$ & $\begin{array}{c}\text { None of the patients developed PI } \\
\text { in the perioperative period using } \\
\text { this therapy. }\end{array}$ \\
\hline A921 & $\begin{array}{l}2011, \\
\text { UK }\end{array}$ & $\begin{array}{l}\text { Controlled randomized trial; } 119 \\
\text { patients were recruited to the } \\
\text { control group and } 120 \text { to the } \\
\text { intervention group; level II }\end{array}$ & $\begin{array}{l}\text { Boot to minimize the pressure on } \\
\text { the heel }\end{array}$ & $\begin{array}{l}\text { Rated by } 59 \% \text { of patients as } \\
\text { comfortable, it reduced the } \\
\text { incidence of calcaneal lesions. }\end{array}$ \\
\hline $\mathrm{A} 10^{22}$ & $\begin{array}{l}\text { 2018, } \\
\text { Brazil }\end{array}$ & $\begin{array}{c}\text { Randomized controlled trial; } 20 \\
\text { patients using support surfaces; } \\
\text { level II }\end{array}$ & Support surfaces & $\begin{array}{l}\text { Sacral and calcaneal regions } \\
\text { suffered less pressure using the } \\
\text { viscoelastic polymer. }\end{array}$ \\
\hline $\mathrm{A} 11^{23}$ & $\begin{array}{l}\text { 2017, } \\
\text { Brazil }\end{array}$ & $\begin{array}{l}\text { Cohort study; } 359 \text { patients } \\
\text { submitted to urological robotic } \\
\text { surgical procedures; level IV }\end{array}$ & $\begin{array}{l}\text { Pressure injury prevention protocol } \\
\text { in the operating room and realistic } \\
\text { simulation }\end{array}$ & $\begin{array}{l}\text { The effectiveness of the protocol } \\
\text { was observed in the surgical } \\
\text { center through the integrated } \\
\text { multiprofessional action, preparing } \\
\text { them for the adequate evaluation } \\
\text { of the risk for injuries. }\end{array}$ \\
\hline $\mathrm{A} 12^{1}$ & $\begin{array}{l}\text { 2016, } \\
\text { Brazil }\end{array}$ & $\begin{array}{c}\text { Methodological research; } 115 \\
\text { patients submitted to surgical } \\
\text { procedures of any specialty; level VI }\end{array}$ & $\begin{array}{l}\text { Construction and validation of } \\
\text { the risk assessment scale for the } \\
\text { development of surgical positioning } \\
\text { injuries (ELPO) }\end{array}$ & $\begin{array}{l}\text { ELPO proved to be a valid and } \\
\text { reliable instrument to evaluate the } \\
\text { risk of developing lesions resulting } \\
\text { from surgical positioning in adult } \\
\text { patients. }\end{array}$ \\
\hline
\end{tabular}

The articles were published between 1998 and 2019, with the year 2017 prevailing with three articles. 
air mattress, which reduces shear, maceration, friction and skin moisture. A positive result was obtained, since in the universe of 28 patients, only one developed PI stage I. The cost of this intervention was US\$18,000 with 28 patients, well below the previous treatment, which was US\$9,134 per patient ${ }^{13}$.

The intraoperative dry viscoelastic polymer mattress reduced the pressure on bone prominences by $9 \%$ compared to the standard mattress, in addition to minimizing friction and shear. However, studies evaluated the different pressures in the bone prominences of the occipital, subscapular, sacral and calcaneal regions with support surfaces containing viscoelastic polymer, sealed and soft foams, and demonstrated that the sacral and calcaneal regions, areas of greater occurrence of PI, obtained greater pressures under the use of viscoelastic polymer, which highlights the need for other associated prevention strategies ${ }^{14,22}$.

The heel is one of the most common sites for the appearance of PI in surgical centers, so numerous devices were designed to decrease the pressure in this region, but it was observed that air mattresses are not as effective for the prevention of PI as those specific for heel. Thus, a boot-shaped device was designed to reduce the pressure of the site by lifting the heel with a cushion held in place by two Velcro tapes, containing inside a foam in the shape of an "egg box". No lesions were observed from this device and it was evaluated by $59 \%$ of the patients as comfortable ${ }^{21}$.

Another preventive therapy widely used in countries with extreme cold was heated blankets, since they reduce the risk of hypothermia related to the reduction of tissue oxygenation, damaging the integrity of the skin. This strategy reduced the appearance of PI in 46\% of surgical patients ${ }^{24}$.

The low-profile alternating pressure overlay is also an effective prevention, since it has a computer-controlled support system, which distributes the patient's weight through small alternating contact nodal points in each body zone, with periodic inflation and disinflation in a five-minute cycle, used throughout the surgical procedure. None of the patients using this therapy was identified to have developed PI in the perioperative period ${ }^{28}$.

Patients who require tracheostomy often have multiple risk factors for the development of PI due to the device, and the installation of preventive measures is important. A study conducted in the United States demonstrated the efficacy of a hydrocolloid dressing under the flange of the immediate postoperative tracheostomy tube, which reduced the incidence of PI from 10.93 to $1.29 \%{ }^{16}$.

\section{Educational interventions}

The educational interventions directed to the multidisciplinary team working in surgical centers had a positive effect on the PI prevention scores, especially with regard to perioperative nurses. These are closest to patients and should be trained in risk factor detection and care management, with knowledge of positioning guidelines $^{19,25,29}$.

The team must be trained both for the implementation of scales and devices for pressure relief, since, through these actions, it is possible to develop technical skills and critical thinking to analyze the best approach to adopt, in accordance with the particularities and specificities of the procedures and risks of each patient. Studies found that nurses in the operating room who received additional education had positive attitudes regarding competence, priority and personal responsibility for PI prevention, emphasizing that training in the work environment is essential in order to cope with this challenge ${ }^{19,23,25}$.

It was also observed in a study conducted in the United States that the institution of a protocol for prevention of PI without prior training of the professionals in the surgical center was not successful, since it reduced only $10 \%$ the number of PIs. However, after the team training, the number of PIs decreased 36\%, reinforcing that continued education, associated with the implementation of updated protocols with training and based on the best scientific evidence is fundamental, because it reduced the lawsuits for negligence, as well as the numbers of morbidity and mortality ${ }^{18}$.

The realistic simulation was another educational intervention for prevention of PI in the surgical center. It should be emphasized that the simulated scenarios allow the professional to get closer to reality, standing out as an opportunity to predict errors and avoid them when they arise in similar situations in the future. This increases the safety of the professional and the surgical patient by preventing events and damage during surgery. In a study in which nurses, nursing technicians, surgeons and anesthesiologists participated, the simulation of surgical positioning was 
performed prior to the procedure. This practice reduced the incidence of PI in surgical patients to zero, configuring a positive strategy when combined with a concise protocol and the involvement of the interdisciplinary team ${ }^{23}$.

One of the limitations of this study was the scarcity of research related to prevention of PI in surgical patients, because the interventions in most of the productions found were focused on PI prevention in other scenarios.

\section{CONCLUSION}

The technological interventions for prevention of pressure injuries in the surgical center were identified as pressure distribution mattresses, device for pressure reduction in the calcaneus, specific validated instruments for classification of PI risk in surgical patients, as well as support surfaces containing viscoelastic polymer and other tools for pressure relief due to weight and medical devices. Regarding educational interventions, protocols, training and realistic simulation were highlighted. These strategies were found to reduce the incidence of PI, in addition to lowering costs and ensuring patient satisfaction.

Technological and educational interventions, when combined, proved effective in the prevention of PI in the surgical center, which emphasizes the importance of expanding these strategies in the health services in order to minimize this problem. Furthermore, studies of high scientific evidence on the subject are suggested to be developed, mainly in the Brazilian scenario, in order to guide good nursing practices in the prevention of PI in the perioperative period.

\section{AUTHOR'S CONTRIBUTION}

Conceptualization; Bezerra, SMG, Brito JFP, Lira JAC, Barbosa NS, Carvalho KG and Sousa LS; Writing - Original Draft; Bezerra, SMG, Brito JFP, Lira JAC, Barbosa NS, Carvalho KG and Sousa LS; Writing Review and Editing; Bezerra, SMG, Brito JFP and Lira JAC; Supervision, Bezerra, SMG, Brito JFP, Lira JAC and Barbosa NS.

\section{REFERENCES}

1. Lopes CMM, Haas VJ, Dantas RAS, Oliveira CG, Galvão CM. Assessment scale of risk for surgical positioning injuries. Rev Latino-Am Enfermagem. 2016;24:e2704. https://doi. org/10.1590/1518-8345.0644.2704

2. Scott SM. Creating a strategic plan for perioperative pressure ulcer prevention. AORN J. 2016;103(4):P13-4. https://doi. org/10.1016/S0001-2092(16)30017-5

3. Cheever KH, Hinkle JL. Brunner \& Suddarth - Tratado de enfermagem médico-cirúrgica. Rio de Janeiro: Guanabara Koogan; 2016.

4. Brasil. Ministério da Saúde. Documento de referência para - Programa Nacional de Segurança do Paciente. Brasília: Ministério da Saúde; 2014. [cited on 2 Aug 2019]. Available at: http://bvsms.saude.gov.br/bvs/publicacoes/documento_ referencia_programa_nacional_seguranca.pdf

5. Engels D, Austin M, McNichol L, Fencl J, Gupta S, Kazi H. Pressure ulcers: factors contributing to their development in the OR. AORN J. 2016;103(3):271-81. https://doi. org/10.1016/j.aorn.2016.01.008

6. Donoso MTV, Barbosa SAS, Simino GPRS, Couto BRGM, Ercole FF, Barbosa JAG. Análise de custos do tratamento de lesão por pressão em pacientes internados. Rev enferm Cent Oeste Min. 2019; 9:e3446. https://doi.org/10.19175/ recom.v9i0.3446
7. Spruce L. Back to basics: preventing perioperative pressure injuries. AORN J. 2017; 105(1):92-9. https://doi.org/10.1016/j. aorn.2016.10.018

8. Menezes S, Rodrigues R, Tranquada R, Müller S, Gama K, Manso T. Injuries resulting from positioning for surgery: incidence and risk factors. Acta Med Port. 2013;26(1):12-6.

9. Paul R, McCutcheon SP, Tregarthen JP, Denend LT, Zenios SA. CE: Sustaining pressure ulcer best practices in a high-volume cardiac care environment. Am J Nurs. 2014;114(8):34-44. https://doi.org/10.1097/01.NAJ.0000453041.16371.16

10. Whittemore $R$, Knafl K. The integrative review: updated methodology. J Adv Nurs. 2005;52(5):546-53. https://doi. org/10.1111/j.1365-2648.2005.03621.x

11. Lockwood C, Porritt K, Munn Z, Rittenmeyer L, Salmond S, Bjerrum $M$, et al. Chapter 2: Systematic reviews of qualitative evidence. In: Aromataris E, Munn Z (Eds.). Joanna Briggs Institute Reviewer's Manual. Adelaide: The Joanna Briggs Institute; 2017.

12. Melnyk BM, Fineout-Overholt E. Making the case for evidence-based practice. In: Evidence-based practice in nursing \& healthcare: a guide to best practice. Philadelphia: Lippincot Williams \& Wilkins; 2005. https://doi.org/10.1037/ t68160-000 
13. Jackson M, McKenney T, Drumm J, Merrick B, LeMaster T, VanGilder C. Pressure ulcer prevention in high-risk postoperative cardiovascular patients. Crit Care Nurse. 2019;31(4):44-52.

14. Nixon J, McElvenny D, Mason S, Brown J, Bond S. A sequential randomised controlled trial comparing a dry visco-elastic polymer pad and standard operating table mattress in the prevention of post-operative pressure sores. Int J Nurs Stud. 1998;35(4):193-203. https://doi.org/10.1016/S00207489(98)00023-6

15. Scott EM, Leaper DJ, Clark M, Kelly PJ. Effects of warming therapy on pressure ulcers - a randomized trial. AORNJ. 2001;73(5):92138. https://doi.org/10.1016/S0001-2092(06)61744-4

16. O'Toole TR, Jacobs N, Hondorp B, Crawford L, Lisa R, Boudreau LR, Jeffe J, et al. Prevention of tracheostomyrelated hospital-acquired pressure ulcers. Otolaryngol Head Neck Surg. 2017;156(4):642-51. https://doi. org/10.1177/0194599816689584

17. Peixoto CA, Ferreira MBG, Felix MMS, Pires PS, Barichello E, Barbosa $\mathrm{MH}$. Risk assessment for perioperative pressure injuries. Rev Latino-Am Enfermagem. 2019;27:e3117. https://doi.org/10.1590/1518-8345.2677-3117

18. Strasser LA. Improving skin integrity in the perioperative environment using an evidence-based protocol. Dermatol Nurs. 2012;4(6):351-60. https://doi.org/10.1097/ JDN.0b013e318274b46c

19. Thenmozhi N, Valliammal B, Kiruba JA. A descriptive study to assess the adequacy of nursing measures carried out to minimize the pressure ulcers during peri-operative period. Int J Nurs Educ. 2017;(9)3:99-102. https://doi. org/10.5958/0974-9357.2017.00077.0

20. Oliveira KF, Rodrigues LP, Barichello E, Chavaglia SRR, Cunha $D F$, Ferreira MBG, et al. Bioimpedance as an indicator in the distribution of interface pressure in vulnerable regions for pressure ulcers: a preliminary study. Int J Nurs Pract. 2019;25(4):e12738. https://doi.org/10.1111/ijn.12738

21. Donnelly J, Winder J, Kernohan WG, Stevenson M. An $\mathrm{RCT}$ to determine the effect of a heel elevation device in pressure ulcer prevention post-hip fracture. J Wound Care. 2011;20(7):309-18. https://doi.org/10.12968/ jowc.2011.20.7.309

22. Oliveira KF, Pires PS, De-Mattia AL, Barichello E, Galvão CM, Araújo CA, et al. Influence of support surfaces on the distribution of body interface pressure in surgical positioning. Rev Latino-Am Enfermagem. 2018;26:e3083. https://doi.org/10.1590/1518-8345.2692.3083

23. Angelo CS, Pachioni CFM, Joaquim EHG, Silva EAL, Santos $\mathrm{GG}$, Bonfim IM, et al. Efetividade do protocolo prevenção de lesões de pele em cirurgias urológicas robóticas. Rev SOBECC. 2017;22(3):152-60.

24. Scott SM. Progress and challenges in perioperative pressure ulcer prevention. J Wound Ostomy Cont. 2015;42(5):480-5. https://doi.org/10.1097/WON.0000000000000161

25. Putnam K. Minimizing pressure ulcer risk for surgical patients. AORN J. 2016;103(4):P7-9. https://doi.org/10.1016/ S0001-2092(16)30009-6

26. Munro CA. The development of a pressure ulcer risk-assessment scale for perioperative patients. AORN J. 2010;92(3):272-87. https://doi.org/10.1016/j. aorn.2009.09.035

27. Yoshimura M, Ohura N, Tanaka J, Ichimura S, Kasuya Y, Hotta O. et al. Soft silicone foam dressing is more effective than polyurethane film dressing for preventing intraoperatively acquired pressure ulcers in spinal surgery patients: the Border Operating room Spinal Surgery (BOSS) trial in Japan. Int Wound J. 2018;15(2):188-97. https://doi.org/10.1111/ iwj.12696

28. Joseph J, McLaughlin D, Darian V, Hayes L, Siddiqui A. Alternating pressure overlay for prevention of intraoperative pressure injury. J Wound Ostomy Continence Nurs. 2019;46(1):13-7. https://doi.org/10.1097/ WON.0000000000000497

29. Ünver S, Fındık ÜY, Özkan ZK, Sürücü Ç. Attitudes of surgical nurses towards pressure ulcer prevention. J Tissue Viability. 2017;26(4):277-8. https://doi.org/10.1016/j.jtv.2017.09.001 